\title{
Comparison and relationship between water parameters and abundance of insects in field and irrigation system of paddy area of Sungai Burong, Tanjung Karang, Selangor, Malaysia
}

\author{
Norazliza R., Fauziah I., Mohd Rasdi Z.*, Fairuz K., Ismail R. \\ Faculty of Plantation and Agrotechnology, Universiti Teknologi MARA, Shah Alam, Malaysia
}

\section{Email address:}

azliza_1708@yahoo.com.my (Norazliza R.), fauziah@salam.uitm.edu.my (Fauziah I.), dddpim@salam.uitm.edu.my (Mohd R. Z.), fairuz@salam.uitm.edu.my (Fairuz K.), ismailrakibe@gmail.com (Ismail R.)

\section{To cite this article:}

Norazliza R., Fauziah I., Mohd Rasdi Z., Fairuz K., Ismail R.. Comparison and Relationship between Water Parameters and Abundance of Insects in Field and Irrigation System of Paddy Area of Sungai Burong, Tanjung Karang, Selangor, Malaysia. Agriculture, Forestry and Fisheries. Vol. 3, No. 4, 2014, pp. 249-256. doi: 10.11648/j.aff.20140304.16

\begin{abstract}
Any disturbance that occurs in agro-ecosystem especially in alteration of water quality has significant effects towards the diversity and distribution of insects. Improper agronomic practices in plantation areas such as the extensive use of fertilizers and pesticides may cause the disturbance of water quality. Thus, affecting the diversity and distribution of the insect communities. Following to that, the intention of this study is to determine the effect of water parameter on abundance of beneficial insects in the paddy field of Sungai Burong at two seasons of sampling periods. Indeed, sampling was done in both paddy plots and drains. The measurement of water temperature, salinity, turbidity, $\mathrm{pH}$, dissolved oxygen (DO in $\mathrm{mg} / \mathrm{L}$ and \%) was analyzed using YSI 550A Multi-parameter probe while the suspended solid, ammonia, Biological Oxygen Demand (BOD) and Chemical Oxygen Demand (COD) were analyzed in the laboratory. The results showed that there were relationships between all beneficial insects with water parameters. Moreover, the water temperature, DO, BOD and COD were good predictors for abundances of beneficial insects which were Anisoptera, Zygoptera, Gerridae and Coccinellidae. Therefore, it was recommended that all farmers maintain the quality of water in inlet, paddy plots and drains at the acceptable level thus, the abundance of beneficial insects can be increased, reducing the dependency on application of insecticides.
\end{abstract}

Keywords: Water Parameter, Insects and Paddy

\section{Introduction}

Diversity of insects in paddy field can be divided into two groups: which are beneficial and insects considered as pests [1]. The beneficial insects are usually known as natural enemies [2] which can be defined as a living organism that kills, harms and causes disease in other organisms. In agricultural point of view, natural enemies are also known as biological agents in biological control for minimizing the population of insect pests. In paddy field, some of the predators in paddy fields are associated with water. Improper agronomic practices in paddy field such as the extensive used of fertilizers and pesticides may cause the disturbance of water quality. Thus, affecting the diversity and distribution of insect communities, considering that some species of insects are very sensitive to pollution and prefer to live in good quality environment with good quality water [3]. Study done by Gossum [4] noted that higher usage and concentrations of Perfluorooctanesulfonic acid (PFOS) in plantation areas can cause reduction in life cycle of damselflies of order Zygoptera and contribute to the high mortality of the larvae. Besides, extensive usage of chemicals in plantation areas may cause the arising of water temperature which had been identified as one of stressful factors to the larvae of Zygoptera. A study done by Chang et al. [5] founds that the development of Copera annulata (Selys) (Odonata: Zygoptera) larvae was agitated as water temperature increased due to high usage of insecticides.

Therefore, the knowledge of survival requirements for predators in paddy field will help to reduce the application of pesticides. Plus, to understand the factors that can affect the populations of beneficial insects in paddy fields is urgently 
needed to increase the population of beneficial insects. Thereby, the intention of this study is to evaluate the effects of water parameters on abundance of insects in the paddy field at Sungai Burong, Tanjung Karang, Selangor, Malaysia.

\section{Material and Methods}

\subsection{Study Area}

The study was conducted in paddy fields at Sungai Burong, one of the largest paddy fields in Malaysia which is located at Tanjung Karang, $\left(3.4167^{\circ} \mathrm{N}, 101.1833^{\circ} \mathrm{E}\right)$ in the state of Selangor. A total of 3221.84 hectares of paddy fields in Sungai Burong are irrigated by the nearby river named as Tengi River.

\subsection{Experimental Design}

A total of 12 stations were identified as sampling areas consisted of two localities namely paddy plots (yellow circle) and paddy drains (red circle), with six collection points in each one, as shown in Figure 1. The paddy inlet (turquoise circle) was the sources of water that were used for irrigate the paddy fields. Samples were carried out for two sampling periods: October to December 2011 and February to May 2012.

\subsection{Samples Collection}

Insects were collected in three replications at each sampling areas. A sweeping net was dragged about one meter, water was collected and took to the laboratory for water analysis in three replications for each test of the water analysis.

The insects were randomly collected using sweeping hand net $(0.5 \mathrm{~mm})$ dragged about one meter. Insects were killed in $90 \%$ of chloroform prior transferred to $70 \%$ of ethyl alcohol solution for preservation.

\subsection{Samples Analysis}

All samples were brought to the laboratory for sorting, classifying and counting. The water parameters namely water temperature, salinity, turbidity, $\mathrm{pH}$ and Dissolved Oxygen (DO) were analyzed using YSI $550 \mathrm{~A}^{\circledR}$ Multi-Parameter probe, while the Chemical Oxygen Demand (COD), Biological Oxygen Demand (BOD), ammonia and Total Suspended Solids (TSS) was analyzed in laboratory using methods that had been adopted from United State Environmental Protection Agency (USEPA).

As for COD, a total of homogenize $2 \mathrm{~mL}$ of paddy water and deionised water (blank sample) were transferred into the COD Digestion reagent vial using pipette. The vial was then placed into the DRB $200^{\circledR}$ reactor which had been preheated to $150^{\circ} \mathrm{C}$. Later than, two hours of heated all vials were allowed to cool at $120^{\circ} \mathrm{C}$ or less. A cool vial was inserted to the cell holder of DR $2800^{\circledR}$ instrument. The instrument was set up and reading was recorded [6].
The BOD of paddy water was analyzed by transferred a total of $355 \mathrm{~mL}$ of paddy water into a clean BOD sample bottle. Then, a magnetic stirring bar of $3.8 \mathrm{~cm}$ and BOD Nutrient Buffer Pillow were placed in the sample bottle. The BOD Nutrient Buffer Pillow was used for optimum of bacterial growth for five days of incubation period. Subsequently, the lip of the sample bottle and seal-cup were sealed using stopcock grease. The lithium hydroxide powder pillow was then transferred into the seal-cup using funnel. Any particles of lithium hydroxide powder pillow were not allowed to fall into the samples. If this occurs, samples need to re-prepare. All prepared samples were placed on the chassis base of BODTrak ${ }^{\mathrm{TM}}$ with all appropriate tube of the BODTrak ${ }^{\mathrm{TM}}$ connected to the sample bottle. Then, the instrument was setup according to the manual procedure. The results of BOD reading that appeared on the screen of BODTrak ${ }^{\mathrm{TM}}$ were recorded after five days of observation [7].

As for ammonia, a total of $25 \mathrm{~mL}$ of water samples and distilled water (blank sample) were measured in measuring cylinder. Then, three drops of mineral stabilizer, three drops of polyvinyl alcohol dispersing agent and $1 \mathrm{~mL}$ of Nessler ${ }^{\mathbb{B}}$ reagent were added to each of cylinder. For each new chemical reagent added, the measuring cylinder needs to invert for several times to mix. A total of $10 \mathrm{~mL}$ of each prepared solution was poured into the sample cell which then was wiped with clean towel prior inserted to the cell holder of DR $2800^{\circledR}$ instrument. The reading that had been displayed on the screen of instrument was then recorded [6].

The TSS analysis was carried out by dried a clean glass fibre filter paper in oven at temperature ranging from 103 to $105^{\circ} \mathrm{C}$ for two hours (Figure 31). After being cool in desiccators, the fibre filter paper was weighing prior placed into the Buchner ${ }^{\circledR}$ flask. While vacuum was applied, $100 \mathrm{~mL}$ of paddy water was dispensed into the glass fibre filter paper to remove all traces. The glass fibre filter paper was washed with $10 \mathrm{~mL}$ of distilled water. The wet glass fibre filter paper was carefully removed and dried at temperature ranging from $103^{\circ} \mathrm{C}$ to $105^{\circ} \mathrm{C}$ for at least one hour. The glass fibre filter paper was cooled and reweighed. The amount of TSS in paddy water was obtained using the following equation [8].

Total Suspended Solid, $\mathrm{mg} / \mathrm{L}=(\mathrm{A}-\mathrm{B}) \times 1000 / \mathrm{C}$ where: $\mathrm{A}=$ weight of filter paper and residue in dish in $\mathrm{mg}$

$\mathrm{B}=$ weight of clean filter paper in dish in $\mathrm{mg}$

$\mathrm{C}=$ volume of paddy water sample filtered in $\mathrm{mL}$

\subsection{Data Analysis}

The Pearson's correlation from Statistical Package for Social Science (SPSS) version 19 was done to determine relationship that may presence between insects and water parameters. In addition, the multiple regression analysis was done to predict effects of selected water parameter on abundance of beneficial insects. The stepwise regression model was done prior to multiple regression analysis [9]. 


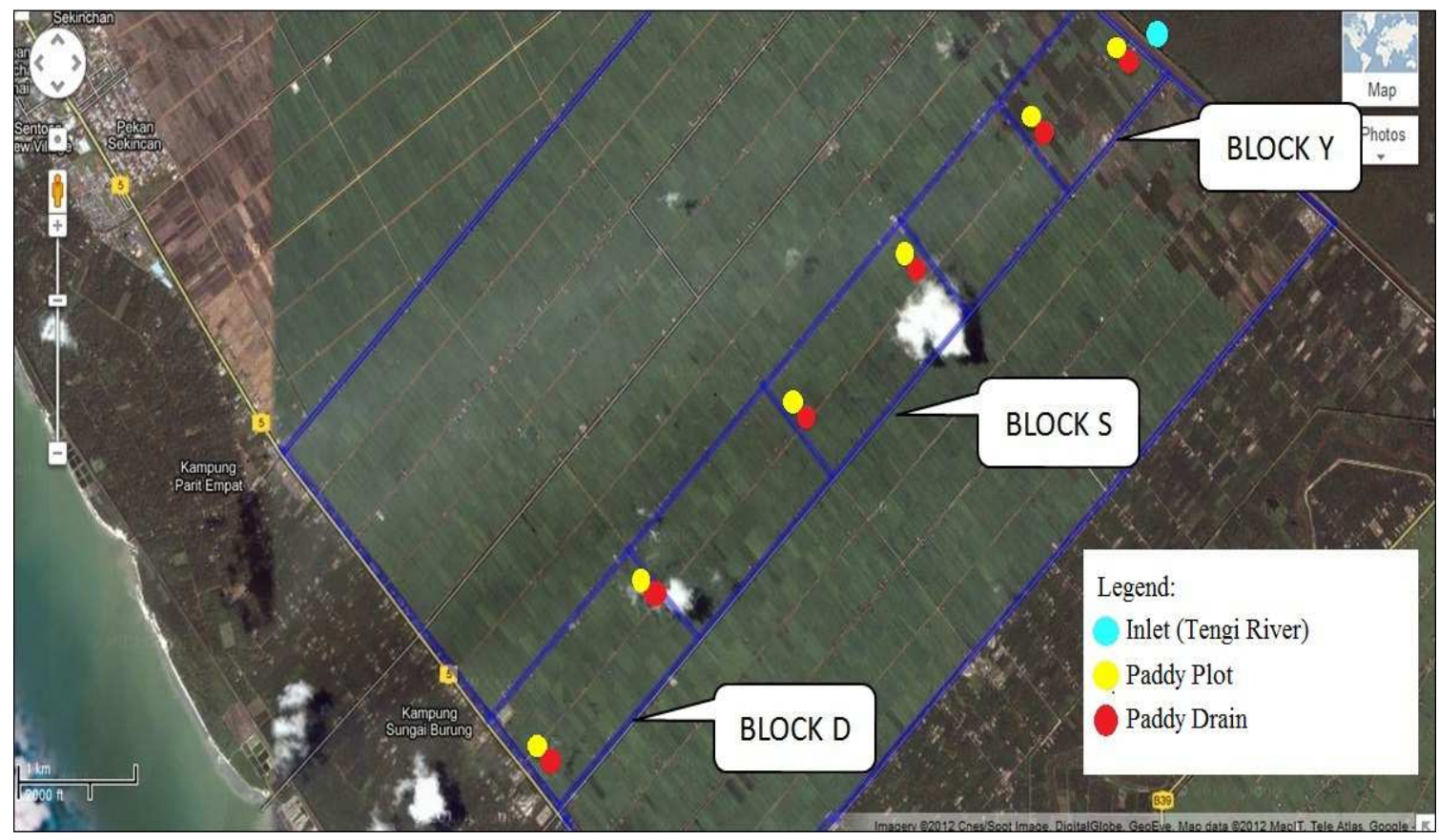

Figure 1. Sampling areas

\section{Results}

\subsection{Composition of the Insects}

A total of 1,257 individuals of insects were successfully counted and classified. In overall, those insects collected were classified into five orders which were Coleoptera, Hemiptera, Lepidoptera, Odonata and Diptera. In addition, a total of two families were found for both insect orders of Hemiptera and Coleoptera. As for Hemiptera, insects from family of Gerridae and Cicadellidae were successfully classified, while for Coleoptera, Coccinellidae and Staphylinidae were found. There was one family found from the orders of Lepidoptera and Diptera namely Pyralidae and Chironomidae, respectively. Furthermore, there were two sub-orders of insects found from insect order of Odonata which were Anisoptera and Zygoptera. Amongst the insect, three of them were recognized as pests. Those insect pests belonged to the family of Pyralidae (Lepidoptera), Cicadellidae (Hemiptera) and Chironomidae (Diptera). The remaining insect's order and families were recognized as beneficial insects in paddy field.

Table 1 shows the mean of insect composition for two sampling periods of paddy planting. In the first sampling of paddy planting, Gerridae had the highest percentage ( 6.31 or $62.6 \%)$ followed by Zygoptera $(2.56 ; 25.4 \%)$, Coccinellidae $(0.53 ; 5.5 \%)$ and Pyralidae $(0.36$ or $0 \%)$. Insects from the order of Anisoptera, Cicadellidae and Staphylinidae have a similar mean with 0.11 (1.1\%) respectively in the first season of paddy planting. In the second sampling of paddy planting, the highest mean of insect sampled was Chironomidae ( 7.00 or $37.6 \%$ ), followed by Gerridae (6.52 or $35 \%)$, Zygoptera (2.96 or $15.9 \%)$, Cicadellidae $(0.92$ or $4.9 \%)$, Staphylinidae $(0.69$ or $3.7 \%)$, Pyralidae $(0.25$ or $1.3 \%)$, Coccinellidae $(0.19$ or $1.0 \%)$ and Anisoptera ( 0.10 or $0.5 \%)$.

Table 1. Insect Compositions (Mean Number and Percentage) on Two Sampling Periods

\begin{tabular}{llll}
\hline \multicolumn{2}{l}{ Season of paddy planting } & & \\
\hline \multicolumn{2}{l}{ Taxonomic composition } & $\mathbf{1}$ & $\mathbf{2}$ \\
\hline \multirow{2}{*}{ Odonata } & Sub-Order: Anisoptera & 0.11 & 0.10 \\
& & $(1.1 \%)$ & $(0.5 \%)$ \\
& Sub-Order: Zygoptera & 2.56 & 2.96 \\
& & $(25.4 \%)$ & $(15.9 \%)$ \\
Hemiptera & Family: Gerridae & 6.31 & 6.52 \\
& & $(62.6 \%)$ & $(35 \%)$ \\
& & 0.11 & 0.92 \\
Family: Cicadellidae & $(1.1 \%)$ & $(4.9 \%)$ \\
& & 0.53 & 0.19 \\
& Family: Coccinellidae & $(5.3 \%)$ & $(1.0 \%)$ \\
& & 0.11 & 0.69 \\
Lepidoptera & Family: Staphylinidae & $(1.1 \%)$ & $(3.7 \%)$ \\
& & 0.36 & 0.25 \\
Diptera & Family: Pyralidae & $(0 \%)$ & $(1.3 \%)$ \\
& & 0.00 & 7.00 \\
& & $(0 \%)$ & $(37.6 \%)$ \\
\hline
\end{tabular}

\subsection{Relationship between Abundance of Insects and Water Parameters}

Throughout the first season of paddy planting (Table 2), there was a significant relationship between Anisoptera and several water parameters. There were positive correlation between Anisoptera and water $\mathrm{pH}(\mathrm{r}=0.725, \mathrm{p}=0.000)$, Dissolved Oxygen $(r=0.705, p=0.000)$ and ammonia $(r=$ $0.354, p=0.034$ ). However, during the second season (Table 22) of paddy planting, Anisoptera only shows positive 
correlation with water turbidity and TSS at $\mathrm{r}=0.508, \mathrm{p}=$ 0.02 and $\mathrm{r}=0.556, \mathrm{p}=0.000$. Furthermore, Anisoptera had shown more correlation with water parameters at both sampling periods than the other orders. The results (Table 3) indicate that there were no significance correlations between Zygoptera with any water parameters during the second season of paddy planting.

Table 2. Relationship of the Abundance of Insects with Water Parameters in the First Seasons of Paddy Planting

\begin{tabular}{|c|c|c|c|c|c|c|c|}
\hline Water Parameters & Anisoptera & Zygoptera & Gerridae & Coccinellidae & Staphylinidae & Pyralidae & Cicadellidae \\
\hline \multirow{4}{*}{ Salinity } & $\mathrm{r}=0.178$ & $\mathrm{r}=0.668^{(\mathrm{s})}$ & $r=-0.325^{(s)}$ & $\mathrm{r}=0.519^{(\mathrm{s})}$ & $\mathrm{r}=0.209$ & $r=0.443^{(s)}$ & $\mathrm{r}=0.115$ \\
\hline & $\mathrm{p}=0.300$ & $\mathrm{p}=0.000$ & $\mathrm{p}=0.053$ & $\mathrm{p}=0.001$ & $\mathrm{p}=0.221$ & $\mathbf{p}=\mathbf{0 . 0 0 7}$ & $\mathrm{p}=0.505$ \\
\hline & $\mathrm{r}=0.175$ & $r=-0.089$ & $\mathrm{r}=0.452^{(\mathrm{s})}$ & $r=-0.294$ & $\mathrm{r}=-0.191$ & $\mathrm{r}=-0.189$ & $\mathrm{r}=-0.117$ \\
\hline & $\mathrm{p}=0.307$ & $p=0.605$ & $\mathrm{p}=0.006$ & $\mathrm{p}=0.082$ & $\mathrm{p}=0.265$ & $\mathrm{p}=0.270$ & $\mathrm{p}=0.499$ \\
\hline \multirow{2}{*}{ Turbidity } & $r=-0.200$ & $\mathrm{r}=0.099$ & $r=-0.179$ & $\mathrm{r}=0.007$ & $r=-0.149$ & $\mathrm{r}=0.014$ & $\mathrm{r}=-0.012$ \\
\hline & $\mathrm{p}=0.243$ & $\mathrm{p}=0.564$ & $\mathrm{p}=0.297$ & $\mathrm{p}=0.969$ & $\mathrm{p}=0.387$ & $\mathrm{p}=0.934$ & $\mathrm{p}=0.947$ \\
\hline \multirow{2}{*}{ Dissolved Oxygen } & $\mathrm{r}=0.705^{(\mathrm{s})}$ & $\mathrm{r}=-0.024$ & $\mathrm{r}=0.473^{(\mathrm{s})}$ & $\mathrm{r}=0.026$ & $\mathrm{r}=0.134$ & $r=-0.115$ & $r=-0.163$ \\
\hline & $\mathrm{p}=0.000$ & $\mathrm{p}=0.890$ & $\mathrm{p}=0.004$ & $\mathrm{p}=0.878$ & $\mathrm{p}=0.436$ & $\mathrm{p}=0.506$ & $\mathrm{p}=0.343$ \\
\hline \multirow{2}{*}{$\mathrm{pH}$} & $\mathrm{r}=0.725^{(\mathrm{s})}$ & $r=-0.066$ & $\mathrm{r}=0.462^{(\mathrm{s})}$ & $r=-0.004$ & $\mathrm{r}=0.042$ & $r=-0.149$ & $r=-0.088$ \\
\hline & $\mathrm{p}=0.000$ & $\mathrm{p}=0.702$ & $\mathrm{p}=0.005$ & $\mathrm{p}=0.982$ & $\mathrm{p}=0.809$ & $\mathrm{p}=0.384$ & $\mathrm{p}=0.611$ \\
\hline \multirow{2}{*}{$\begin{array}{l}\text { Biological Oxygen } \\
\text { Demand }\end{array}$} & $\mathrm{r}=0.306$ & $r=-0.164$ & $\mathrm{r}=0.110$ & $\mathrm{r}=0.029$ & $\mathrm{r}=0.344^{(\mathrm{s})}$ & $r=-0.011$ & $\mathrm{r}=0.200$ \\
\hline & $\mathrm{p}=0.069$ & $\mathrm{p}=0.339$ & $\mathrm{p}=0.524$ & $p=0.867$ & $\mathrm{p}=0.040$ & $\mathrm{p}=0.951$ & $\mathrm{p}=0.243$ \\
\hline \multirow{2}{*}{$\begin{array}{l}\text { Chemical Oxygen } \\
\text { Demand }\end{array}$} & $r=-0.147$ & $r=-0.286$ & $\mathrm{r}=0.291$ & $\mathrm{r}=-0.438^{(\mathrm{s})}$ & $r=-0.249$ & $r=-0.200$ & $r=-0.231$ \\
\hline & $\mathrm{p}=0.392$ & $\mathrm{p}=0.091$ & $\mathrm{p}=0.085$ & $\mathrm{p}=0.008$ & $\mathrm{p}=0.143$ & $\mathrm{p}=0.243$ & $\mathrm{p}=0.176$ \\
\hline \multirow{2}{*}{ Ammonia } & $\mathrm{r}=0.354^{(\mathrm{s})}$ & $\mathrm{r}=0.038$ & $\mathrm{r}=-0.051$ & $\mathrm{r}=0.187$ & $\mathrm{r}=0.055$ & $r=-0.112$ & $\mathrm{r}=0.129$ \\
\hline & $\mathrm{p}=0.034$ & $\mathrm{p}=0.826$ & $p=0.766$ & $\mathrm{p}=0.276$ & $\mathrm{p}=0.750$ & $\mathrm{p}=0.515$ & $\mathrm{p}=0.455$ \\
\hline \multirow{2}{*}{$\begin{array}{l}\text { Total Suspended } \\
\text { Solid }\end{array}$} & $r=-0.239$ & $\mathrm{r}=0.219$ & $r=-0.221$ & $r=-0.096$ & $r=-0.181$ & $\mathrm{r}=0.201$ & $r=-0.024$ \\
\hline & $\mathrm{p}=0.160$ & $\mathrm{p}=0.200$ & $p=0.196$ & $\mathrm{p}=0.579$ & $\mathrm{p}=0.291$ & $\mathrm{p}=0.239$ & $\mathrm{p}=0.888$ \\
\hline
\end{tabular}

Note: ${ }^{(\mathrm{s})}$ Correlation is significant at the 0.01 level (2-tailed) and 0.05 level (2-tailed); $\mathrm{r}=$ Pearson's correlation; $\mathrm{p}=$ significance $(2$-tailed); Sample size $=$ 36

Table 3. Relationship of the Abundances of Insects with Water Parameters in the Paddy Field at Second Season of Paddy Planting

\begin{tabular}{|c|c|c|c|c|c|c|c|c|}
\hline $\begin{array}{l}\text { Water } \\
\text { Parameters }\end{array}$ & Anisoptera & Zygoptera & Gerridae & Coccinellidae & Staphylinidae & Pyralidae & Cicadellidae & Chironomidae \\
\hline \multirow{2}{*}{ Temperature } & $\mathrm{r}=0.318$ & $\mathrm{r}=0.149$ & $\mathrm{r}=0.107$ & $\mathrm{r}=0.104$ & $\mathrm{r}=0.050$ & $\mathrm{r}=0.197$ & $\mathrm{r}=0.107$ & $\mathrm{r}=0.125$ \\
\hline & $\mathrm{p}=0.059$ & $\mathrm{p}=0.387$ & $\mathrm{p}=0.535$ & $\mathrm{p}=0.545$ & $p=0.772$ & $\mathrm{p}=0.249$ & $\mathrm{p}=0.533$ & $\mathrm{p}=0.469$ \\
\hline \multirow{2}{*}{ Salinity } & $\mathrm{r}=-0.020$ & $r=-0.079$ & $\mathrm{r}=0.360^{(\mathrm{s})}$ & $r=-0.009$ & $r=-0.040$ & $\mathrm{r}=-0.139$ & $r=-0.089$ & $r=-0.078$ \\
\hline & $\mathrm{p}=0.907$ & $\mathrm{p}=0.645$ & $\mathrm{p}=0.031$ & $\mathrm{p}=0.957$ & $\mathrm{p}=0.815$ & $\mathrm{p}=0.417$ & $\mathrm{p}=0.606$ & $\mathrm{p}=0.651$ \\
\hline \multirow{2}{*}{ Turbidity } & $\mathrm{r}=0.508^{(\mathrm{s})}$ & $\mathrm{r}=0.104$ & $\mathrm{r}=0.101$ & $\mathrm{r}=0.008$ & $\mathrm{r}=0.129$ & $r=-0.116$ & $r=-0.050$ & $r=-0.023$ \\
\hline & $\mathrm{p}=0.002$ & $\mathrm{p}=0.545$ & $\mathrm{p}=0.559$ & $p=0.964$ & $\mathrm{p}=0.455$ & $\mathrm{p}=0.502$ & $\mathrm{p}=0.774$ & $\mathrm{p}=0.896$ \\
\hline Dissolved & $r=-0.030$ & $\mathrm{r}=0.195$ & $\mathrm{r}=-0.116$ & $\mathrm{r}=0.267$ & $r=-0.084$ & $\mathrm{r}=0.068$ & $\mathrm{r}=0.190$ & $r=-0.070$ \\
\hline Oxygen & $\mathrm{p}=0.862$ & $\mathrm{p}=0.254$ & $\mathrm{p}=0.501$ & $\mathrm{p}=0.115$ & $\mathrm{p}=0.625$ & $\mathrm{p}=0.695$ & $\mathrm{p}=0.268$ & $\mathrm{p}=0.684$ \\
\hline \multirow{2}{*}{$\mathrm{pH}$} & $\mathrm{r}=0.244$ & $\mathrm{r}=0.029$ & $\mathrm{r}=0.078$ & $r=-0.189$ & $r=-0.013$ & $\mathrm{r}=0.044$ & $\mathrm{r}=0.030$ & $r=0.126$ \\
\hline & $\mathrm{p}=0.152$ & $\mathrm{p}=0.866$ & $p=0.650$ & $\mathrm{p}=0.269$ & $\mathrm{p}=0.938$ & $p=0.797$ & $\mathrm{p}=0.861$ & $\mathrm{p}=0.462$ \\
\hline Biological & $\mathrm{r}=0.124$ & $\mathrm{r}=0.254$ & $\mathrm{r}=0.203$ & $\mathrm{r}=0.243$ & $\mathrm{r}=0.183$ & $\mathrm{r}=0.181$ & $\mathrm{r}=0.058$ & $\mathrm{r}=0.132$ \\
\hline $\begin{array}{l}\text { Oxygen } \\
\text { Demand }\end{array}$ & $\mathrm{p}=0.471$ & $\mathrm{p}=0.134$ & $\mathrm{p}=0.236$ & $\mathrm{p}=0.154$ & $\mathrm{p}=0.285$ & $\mathrm{p}=0.291$ & $\mathrm{p}=0.738$ & $\mathrm{p}=0.442$ \\
\hline Chemical & $r=-0.213$ & $\mathrm{r}=0.233$ & $\mathrm{r}=0.280$ & $\mathrm{r}=0.168$ & $r=0.266$ & $\mathrm{r}=0.188$ & $\mathrm{r}=0.121$ & $\mathrm{r}=0.055$ \\
\hline $\begin{array}{l}\text { Oxygen } \\
\text { Demand }\end{array}$ & $\mathrm{p}=0.213$ & $\mathrm{p}=0.171$ & $\mathrm{p}=0.099$ & $\mathrm{p}=0.326$ & $\mathrm{p}=0.117$ & $\mathrm{p}=0.271$ & $\mathrm{p}=0.480$ & $\mathrm{p}=0.751$ \\
\hline \multirow{2}{*}{ Ammonia } & $r=-0.094$ & $\mathrm{r}=0.263$ & $\mathrm{r}=0.244$ & $\mathrm{r}=0.084$ & $r=-0.013$ & $\mathrm{r}=0.160$ & $r=-0.072$ & $r=-0.057$ \\
\hline & $\mathrm{p}=0.587$ & $\mathrm{p}=0.121$ & $\mathrm{p}=0.152$ & $\mathrm{p}=0.626$ & $\mathrm{p}=0.942$ & $\mathrm{p}=0.350$ & $p=0.676$ & $\mathrm{p}=0.742$ \\
\hline Total & $\mathrm{r}=0.556^{(\mathrm{s})}$ & $r=-0.140$ & $r=-0.285$ & $\mathrm{r}=-0.118$ & $\mathrm{r}=0.049$ & $\mathrm{r}=0.043$ & $r=-0.032$ & $\mathrm{r}=0.289$ \\
\hline $\begin{array}{l}\text { Suspended } \\
\text { Solid }\end{array}$ & $\mathrm{p}=0.000$ & $\mathrm{p}=0.416$ & $\mathrm{p}=0.092$ & $\mathrm{p}=0.491$ & $\mathrm{p}=0.778$ & $\mathrm{p}=0.805$ & $\mathrm{p}=0.855$ & $\mathrm{p}=0.087$ \\
\hline
\end{tabular}

Note: ${ }^{(s)}$ Correlation is significant at the 0.01 level (2-tailed) and 0.05 level $(2$-tailed $) ; r=$ Pearson's correlation; $\mathrm{p}=$ significance $(2$-tailed $) ;$ Sample size $=36$

However, at the first season of paddy planting, Zygoptera had recorded significance positive correlation with water temperature at $\mathrm{r}=0.668$ and $\mathrm{p}=0.000$.

A significance relationship was recorded between Gerridae and several water parameters during the first season of paddy planting. The highest r-value recorded for Gerridae during the first season of paddy planting was DO ( $\mathrm{r}$
$=0.473, \mathrm{p}=0.004)$ followed by $\mathrm{pH}(\mathrm{r}=0.462, \mathrm{p}=0.005)$, salinity $(\mathrm{r}=0.452, \mathrm{p}=0.006)$ and temperature $(\mathrm{r}=-0.325, \mathrm{p}$ $=0.053)$. Meanwhile, there was a significance negative correlation between Gerridae and water temperature. This indicate that population of Gerridae was decreased as the water temperature in the paddy field was increased. During the second season of paddy planting, the abundance of 
Gerridae was positively correlated with water salinity at $\mathrm{r}=$ $0.360, \mathrm{p}=0.031$.

During the first season of paddy planting, Coccinellidae responded to water temperature $(\mathrm{r}=0.519, \mathrm{p}=0.001)$, but negatively correlated with COD $(r=0.438, p=0.008)$. Meanwhile, Staphylinidae was positively correlated with BOD $(r=0.344, p=0.040)$.

The Pyralidae (moth) was observed to be the only insect pest that corresponded to the water parameter in the first sampling. The Pyralidae has positive relationship with water temperature $(r=0.443, p=0.007)$. However, at the second seasons of paddy planting, none of insect pests showed any significant relationship with water parameters. Besides, the abundance of Zygoptera, Coccinellidae and Staphylinidae were not corresponded with water parameters throughout the second sampling season although there was a significant correlation detected at the first season of paddy planting.

Table 4. Multiple Regression Analysis between Beneficial Insects and Water Parameters on the First Season of Paddy Planting

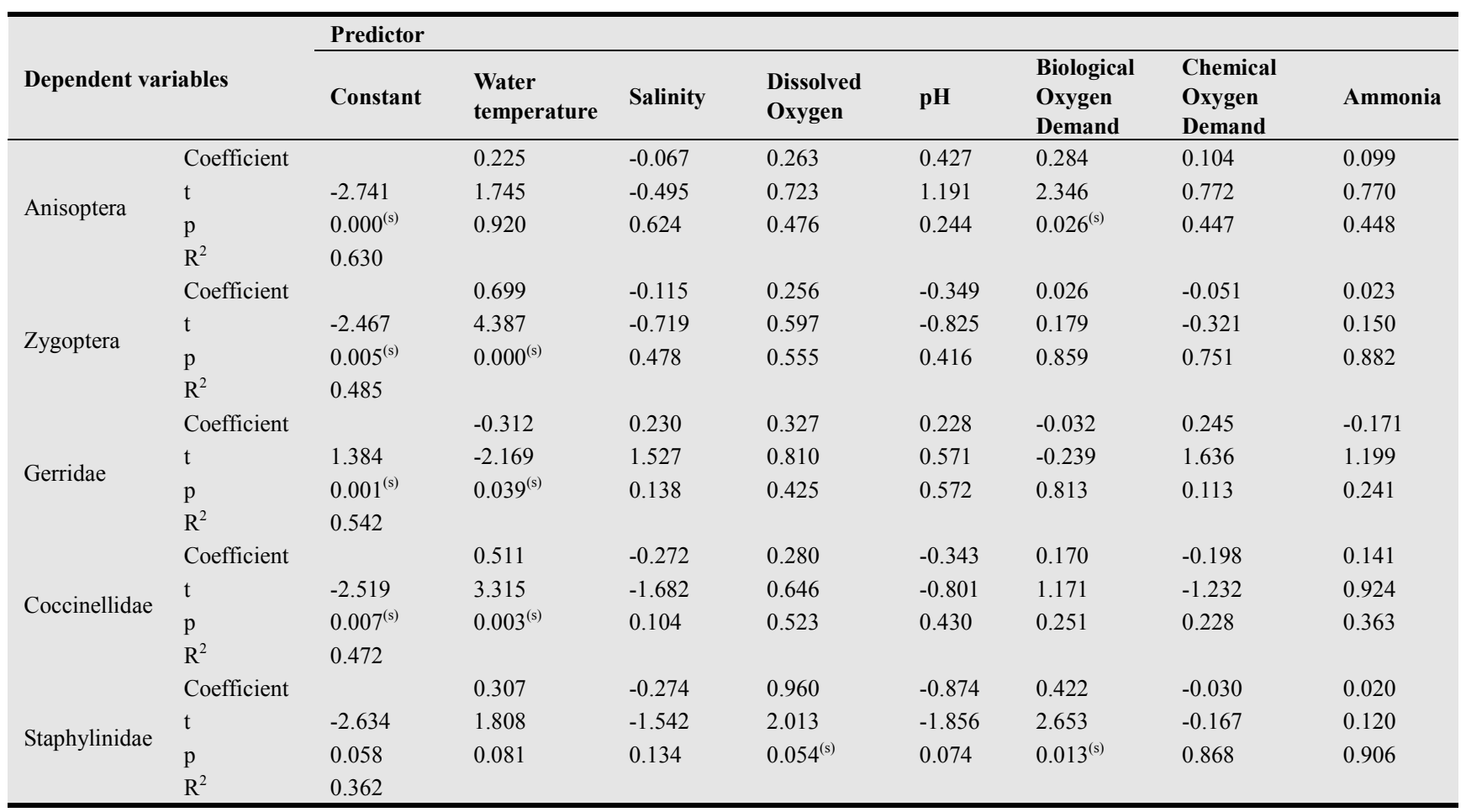

Note: ${ }^{(\mathrm{s})}$ significance at $\mathrm{p}<0.05$

\subsection{Effect of Water Parameters on Abundance of Insects}

The $\mathrm{R}^{2}$ values for the first season of paddy planting (Table 4) shows that $63 \%$ of abundance of Anisoptera in the paddy field can be explained by the water parameters. Moreover, the water parameter that more influenced and well predict to the abundance of Anisoptera was BOD $(p<0.05)$. In the second season, the $\mathrm{R}^{2}$ value of the multiple regression models was low for Anisoptera as $48.5 \%$ (Table 5). Nevertheless, the water temperature was a good predictor to the abundance of the Zygoptera $(\mathrm{p}<0.05)$.

The multiple regression models to predict the effects of water parameters on abundances of Gerridae in the paddy field were only significance for the first sampling. The overall significance of the regression model between Gerridae and water parameter for the both seasons were 0.001 (Table 4) and 0.419 (Table 5) respectively. The $\mathrm{R}^{2}$ value of the multiple regression models for first sampling for Gerridae was 0.542 (Table 4). Therefore, about $54.2 \%$ of water parameters were influenced the abundance of the Gerridae in the paddy field. Furthermore, amongst the water parameters, only water temperature showed significant difference with the abundance of Gerridae.

The overall significance of the regression model between the Coccinellidae and water parameters was $0.007(\mathrm{p}<0.05)$ for the first sampling and $0.162(p>0.05)$ for the second sampling of the paddy plant (Tables 4 and 5 respectively). Therefore, only multiple regression models for the first sampling were accepted in order to predict the effects of the water parameters on the abundance of Coccinellidae in the paddy field. The value of the $\mathrm{R}^{2}$ for the multiple regression models was low (0.472).

The multiple regression model for Staphylinidae for two seasons of paddy planting (Tables 4 and 5) were not validate to predict the effects of water parameters on abundance of Staphylinidae in the paddy field at Sungai Burong. In overall, the significance of the regression model for season 1 and 2 of paddy planting were 0.058 and $0.214(\mathrm{p}>0.05)$ respectively.

Table 4 and 5 shows that both turbidity and total suspended solids were excluded in all analysis since the variable was failed to meet the selection criteria as indicate 
by non significant $\mathrm{t}$-value; $\mathrm{p}>0.05$.

Table 5. Multiple Regression Analysis between Beneficial Insects and Water Parameters on the Second Season of Paddy Planting

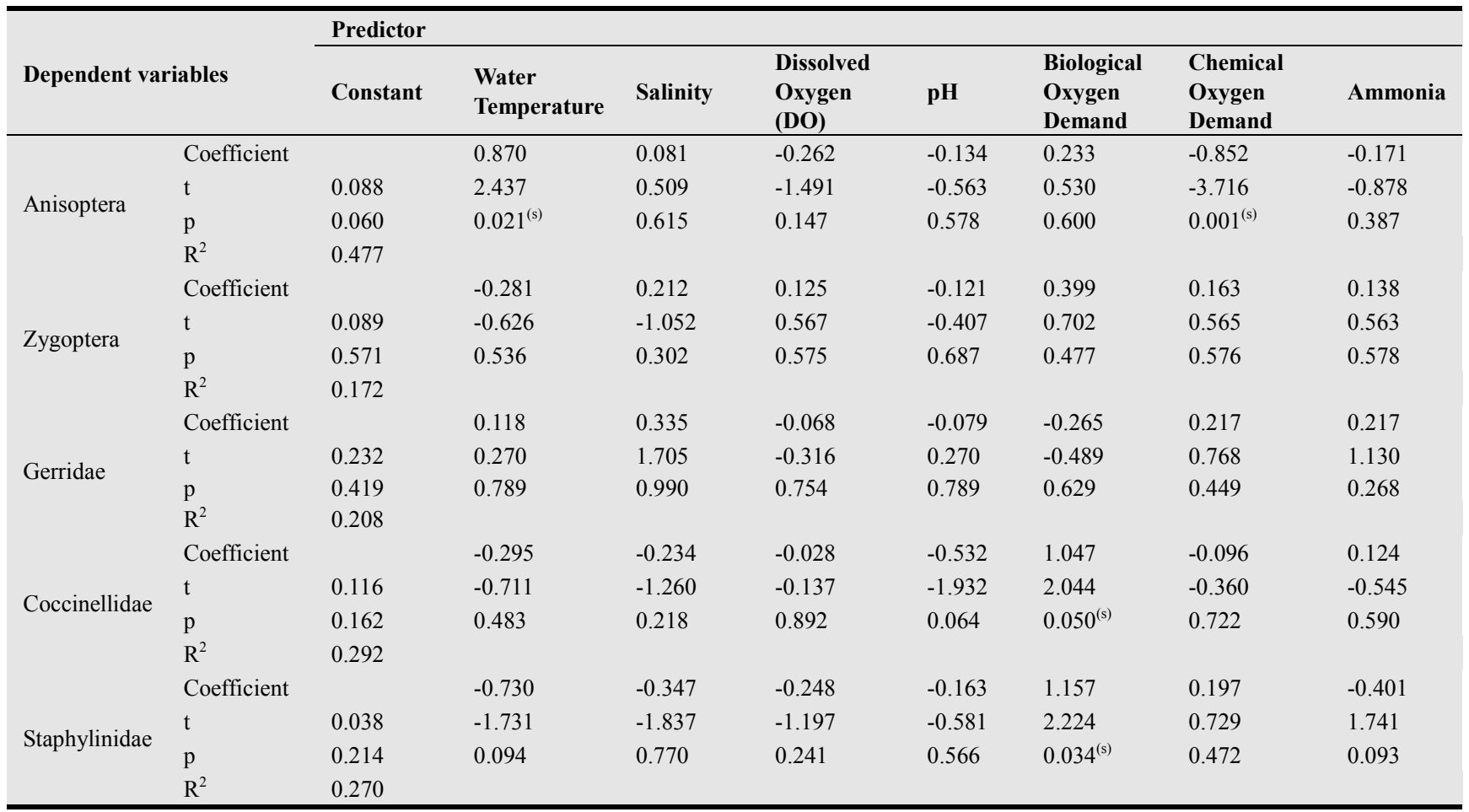

Note: ${ }^{(s)}$ significance at $\mathrm{p}<0.05$

\section{Discussion}

\subsection{Composition of the Insect}

The first sampling was conducted in wet season (October 2011-December 2011) when the occurrence of the rainfall was relatively high while the second sampling was done in the dry season (February 2012-May 2012) which the occurrence of the rainfall was moderately low. Study by Basset [10] noted that the abundance of some herbivore insects during a particular sampling period was significantly influenced by the rainfall and surrounding vegetation.

Besides, the monoculture cropping pattern that had been applied in the paddy field also has a significant influence in the composition and diversity of the insects. Monoculture means that only single crop was planted over a wide area for long consecutive years. According to Andow [11]; Hoffman [12]; Clergue et al. [13] and Berry et al. [14], the extents of monoculture practices have a significant impact to the population of the insects due to the abundance of food sources that discourages the insects to migrate for searching a new host plant. Therefore, increasing in monoculture practices will increase the population of insects. The paddy cultivation in Sungai Burong was manned by the older generation since many years ago [15]. Therefore, monoculture had been adopted for a long time which allowed the insects to colonize. In addition, the paddy plants were planted bound together and the distance from one plot to another plot was only a narrow drainage. Therefore, insects in paddy field easily find their food due to abundance of food sources, thus those insects have a low mobility.

\subsection{Relationship and Effects of Water Parameters on Abundance of Insects}

The results of Pearson's correlation indicate that both Anisoptera and Gerridae had significant correlation with $\mathrm{pH}$ water. A similar situation was also observed by Fox and Cham [16] as Anisoptera had a significantly higher positive correlation to water $\mathrm{pH}$ at the probability value of $\mathrm{p}=0.01$. However, this study was conducted at the national botanical garden in Africa which the locations consisted of fast and slow flowing stream, river and waterfall. Plus, Wahizatul et al. [17] found that aquatic insects from orders Odonata, Coleoptera, Hemiptera, Lepidoptera and Diptera had a significantly positive correlation with $\mathrm{pH}$. The study was conducted in two freshwater streams in Hulu Terengganu, Malaysia. A suitable water $\mathrm{pH}$ was needed by aquatic insects to survive as $\mathrm{pH}$ below 6 or above 8 would cause unfavorable conditions for the reproduction of most aquatic insects [18]. The water temperature showed significantly correlated with Zygoptera, Gerridae, Coccinellidae and Pyralidae. According to Corbet [19], water temperature was known as one of the factors present in the habitat that affects Zygoptera preferences for oviposition. Suh and Samways [20] noted that there was a high significant correlation between Odonata (Anisoptera and Zygoptera) and water temperature and temperature. There were no specific researches evaluating for the relationship between water 
temperature and Gerridae, however, study by Nummelin et al. [21] stated that water striders were good in accumulating of iron and manganese. The presence of heavy metal (iron and manganese) in water caused increasing in the water temperature. Therefore, there was a possibility that water striders could tolerate high water temperature.

The Coccinellidae, Pyralidae and Staphylinidae were recognized as terrestrial insects in the paddy field. According to the Pearson's correlation results, both Coccinellidae and Pyralidae had significance correlation with water temperature during the first season of paddy planting, while the Staphylinidae showed significant correlation with BOD. Besides, Coccinellidae also shows significant correlation with COD during the first season of paddy planting. Findings of this study suggest that there is a possibility of indirect relationship between water plant uptake and the abundance of Coccinellidae, Pyralidae and Staphylinidae in the paddy field. The water temperature can be influenced by environmental factors such as rainfall, temperature and vegetative shading around the sampling area [22]. Besides that, water temperature is also influenced by concentration of pesticides and fertilizers application [4].

Based on the results, correlation between TSS and abundance of insects was only detected during the second season of paddy planting. According to the Fox and Charm [16], TSS was one of importance factors in biology of Odonata (both Anisoptera and Zygoptera) since the presence of solids in the water helps those insects to breed and to colonize.

The results of multiple regression models showed that these models could predict (significance values of overall regression models were below $0.05(p<0.05)$ the effects of selected water parameters on abundance of beneficial insects in the paddy field. The results of multiple regression models showed that there is a relation, at the $95 \%$ confidence level, between the effects of water parameters and the abundance of beneficial insects in the paddy field. However, the water parameters selected in this research were not enough to explain the abundance of the beneficial insects in the paddy plants due to low $\mathrm{R}^{2}$ values. Probably there are further factors that could influence the abundance of insects in the paddy field.

\section{References}

[1] Department of Agricultural-Malaysia, DoA (2010). Buku Maklumat Jabatan Pertanian 2010. Malaysia, 44 pp.

[2] Woperies, M.C.S., Defoer, T., Idinoba, P., Diack, S., and Dugue, M.S. (2009). Technical Manual: Curriculum for participatory learning and action research (PLAR) for Integrated Rice Management (IRM) in Inland Valleys of Sub-Saharan Africa. African Rice Center (WARDA). ISBN 9291133248. 115 pp.

[3] Mohd Rasdi, Z., Fauziah, I., Ismail, R.., Mohd Hafezan, S., Fairuz, K., Hazmi, A. D. and Che Salmah, M.R. (2012). Diversity of Aquatic Insects in Keniam River, National Park, Pahang, Malaysia, Asian Journal of Agriculture and Rural
Development, 2(3), 312-328.

[4] Gossum, H.V., Bots, J., Snijkers T., Meyer, J., Wassenbergh, S.W., Coen, W.D. and Bruyn, L.D. (2009). Behaviour of Damselfly Larvae (Enallagma: Cyathigerum) (Insecta, Odonata) After Long-Term Exposure to PFOS. Journal of Environmental Pollution, 157, 1332-1336.

[5] Chang, X., Zhai, B., Liu, X. and Wang, M. (2007). Effects of Temperature Stress and Pesticide Exposure on Fluctuating Asymmetry and Mortality of Copera Annulata (Selys) (Odonata: Zygoptera) Larvae. Journal of Ecotoxicology and Environmental Safety, 67, 120-127.

[6] Hach. (2007). DR 2800 Spectrometer Prosedures Manual. Hach Company, printed in German.

[7] Hach. (2010). Bodtrak ${ }^{\mathrm{TM}}$ II User Manual (Second edition). Hach Company, printed in China.

[8] USEPA, United States Environmental Protection Agency (2004). Wadeable Streams Assessment Water Chemistry Laboratory Manual. 47 pp.

[9] Field, A. (2009). Discovering Statistical using SPSS (Third Edition). London, SAGE Publications. $821 \mathrm{pp}$.

[10] Basset, Y. (1999). Diversity and abundance of insect herbivores collected on Castanopsis acuminatissima (Fagaceae) in New Guinea: Relationship with leaf production and surrounding vegetation. European Journal of Entomology, 96 (4), 381-391.

[11] Andow, D. (1983). The Extent of Monoculture and Its Effects on Insect Pest Populations with Particular Reference to Wheat and Cotton. Journal of Agriculture, Ecosystems and Environment, 9, 25-35.

[12] Hoffman, W. (1995). Ecology of Agricultural Monocultures: Some Consequences for Biodiversity in Biomass Energy Farm. Proceeding of the $2^{\text {nd }}$ Biomass Conference of the Americas, 1995. 1618-1627.

[13] Clergue, B., Amiaud, B., Pervanchon, F., Lasserre-Joulin, F. and Plantureux, S. (2005). Biodiveristy: Function and Assessment in Agricultural Areas. A Review. INRA, EDP Sciences, 25, 1-15. doi: 10.1051/agro:2004049

[14] Berry, S.D., Rhondes, R., Foster, J., Risede, J.M. and Antwerpen, R.V. (2011). The Effect of Cover Crops on Plant Parasitic-Nematodes of Sugarcane. International Journal of Pest Management, 57 (4), 363-375. doi: 10.1080/09670874.2011.621984.

[15] Perpustakaan Awam Cawangan Tanjung Karang from http://telecentre.my/tanjungkarang/index.php/en/front-page. html. Acesses in January, 2012.

[16] Fox, A.D. and Cham, S.A. (1994). Status, Habitat Use and Conservation of the Scarce Blue-Tailed Damselfly Ischnura Pumilio (Charpentier) (Odonata: Coenagrionidae) in Britain and Ireland. Journal of Biological Conservation, 68, 115-122.

[17] Wahizatul, A.A., Long, S.H. and Ahmad, A. (2011). Composition and Distribution of Aquatic Insect Communities in Relation to Water Quality in Two Freshwater Streams of Hulu Terengganu, Terengganu. Journal of Sustainability Science and Management, 6(1), 148-155. 
[18] Namoi Catchment Management Authority. (2013). Water Quality Parameters and Indicator. New South Wales: Stephanie McCaffrey. Retrieved from http://www.waterwatch.nsw.gov.au.

[19] Corbet, P.S. (1962). A Biology of Dragonflies. London: H. F.and G. Witherby Ltd., 136 pp.

[20] Suh, A.N. and Samways, M. J. (2001). Development of Dragonfly Awareness Trail in an African Botanical Garden.
Journal of Biological Conservation, 100, 345-353.

[21] Nummelin, M., Lodenius, M., Tulisalo, E., Hirvonen, H., Alanko, T. (2007). Predatory Insects as Bioindicators of Heavy Metal Pollution. Journal of Environmental Pollution, 14, 339-347.

[22] EPA (Environmental Protection Agencies, Unite States) (2012). Chapter 5: Water Quality Monitoring. Retrived from http://water.epa.gov/type/rsl/monitoring/vms50.cfm 